\title{
Academic libraries in COVID-19: a renewed mission for digital literacy.
}

\author{
MARTZOUKOU, K.
}

2021

This author accepted manuscript is deposited under a Creative Commons Attribution Non-commercial 4.0 International (CC BY-NC) licence. This means that anyone may distribute, adapt, and build upon the work for non-commercial purposes, subject to full attribution. If you wish to use this manuscript for commercial purposes, please contact permissions@emerald.com. 


\title{
Academic libraries in COVID-19: A renewed mission for digital literacy
}

Dr Konstantina Martzoukou

\section{Library Management Journal Special Issue}

October 2020

\begin{abstract}
Purpose: The COVID-19 pandemic has placed online learning, blended or hybrid provision as the "new normal' in Higher Education. For most universities and their academic libraries, especially those with a less strong online presence, the pandemic has caused numerous challenges. However, it has also been a catalyst for change and resifting of priorities. For academic librarians involved in the delivery of information skills/literacy training, a renewed mission is emerging, addressing access and connectivity to resources, designing for online education and fostering the development of digital literacy of students.
\end{abstract}

Design/methodology/approach: This is a conceptual paper based on the author's personal experiences and subjective opinion as a Library and Information Science educator with considerable expertise in online distance learning in the U.K. Reflecting critically on the impact of the pandemic from an educational point of view and on key changes experienced, the paper centres on the argument that academic librarians could emerge as strategic partners in Higher Education, towards the direction of enhancing students' digital competences development.

Findings: The complete and involuntary shift to online learning due to COVID-19 restrictions, has opened the door to multiple challenges in Higher Education, which are complex and ongoing: the implementation of remote tools and practices en masse in online teaching and learning in a way that ensures accessibility and equity for all, issues connecting to online pedagogy, and how to prepare students with the information and digital literacy competences required for the new online learning 'normal'. As academic libraries move forward, they have a renewed mission to help learners in the online space to become both information rich and digitally competent. There is an opportunity to act as the connecting link that will help to move a step forward a strategic vision that places design for equity at the center of education.

Originality/value: The impact of COVID-19 within Higher Education and academic libraries more specifically, is a theme that has not been yet sufficiently discussed, researched or critically debated as the world is still currently going through the pandemic crisis. This paper aims to initiate some early thoughts and conversation as well as put forward the author's personal critical positioning on the issues, challenges and potential opportunities emerging in the current educational climate for academic 
librarians and to highlight areas of importance for the design and direction of information and library science curricula.

Keywords: COVID-19, pandemic, higher education, academic librarians, information skills, disinformation, fake news, digital competences, digital literacy, information literacy, digital divide.

Article Classification: Opinion pieces.

\section{Introduction: COVID-19 and Higher Education Teaching and Learning}

The COVID-19 pandemic has created an unpredictable situation for many Higher Education institutions across the globe, as online learning, and blended or hybrid provision (drawing on both physical and virtual learning) have now became rapidly the new education reality, based on the anticipation, that, at least for the near future, fewer students are likely to be present fully on-campus. Naturally, the rapid, disaster-facing situation created by COVID-19 has forced universities to make short-term changes with an emphasis on overcoming what has been considered to be a temporal situation, which will be reverted once social distancing rules are no longer in place and 'normality' is returned to the traditional classroom. Emphasis, in that way, has been mostly placed on surviving the present crisis and, often, putting in place short-lived or ephemeral plans, which can be easily changeable, depending on the dayto-day restrictions and additional social distancing regulations, imposed by governments, in an effort to control the pandemic.

However, the present crisis has already created radical shifts for Higher Education institutions, some of which, under normal circumstances, would have taken years to materialise due, for example, to logistic, operational or bureaucratic hurdles, or simply because of a managerial or higher-level strategic resistance to 'new ways of thinking', which could have challenged established teaching and learning practices and tested-out formulas, creating, in that way, prolonged change management timelines. Of course, even predating the COVID-19 situation, there was already a high adoption of technology and online tools usage in teaching, scholarship and research collaborative activities across universities. For example, when the global pandemic hit, the provision of online teaching, learning and assessment were not a new undiscovered territory for universities across the globe, that had already been developing significant pockets of expertise on the use of diverse online technologies and the provision of a range of online resources and activities (e.g. digitised learning material, lecture capture content, synchronous and asynchronous online teaching and communication sessions, 'how-to' video tutorials and overview 
sessions, flipped classrooms, e-tutoring opportunities, audio and video feedback, screen capture demonstrations, online quizzes and multimedia demos, and virtual reality simulations and simulations).

This evolving digital reality of academia that has unfolded before the pandemic, has also already signified a parallel digital transformation for the academic library, which is at the heart of academic institutions. Academic libraries have been at the forefront of supporting the provision of flexible online learning resources, online services and training, positioning librarians to take on a leading role in supporting students and staff to develop information and digital literacy skills via online courses, tutorials, workshops and e-consultations. For example, a recent report by EBLIDA found that during COVID 19, because universities and research institutes across the world, had already been working in areas that supported students and staff online, and because staff were already utilising these resources for years, access to library research digital material demonstrated only a moderate growth (EBLIDA, 2020; p. 5).

However, although offering online access to resources is common in many universities, the full-time online provision of courses has been less prominent, with only a small proportion of universities having embraced online learning pre COVID-19. For example, in England although there is a high number of private training providers, prior to COVID-19, few Higher Education Institutions had been delivering online courses (although many were working in partnership with MOOC platforms) (Zaidi, et al., 2018; p.7). In the UK, overall, an earlier report published by Universities UK, states that, although universities have incorporated more flexibility in their learning and teaching design to accommodate students with working and caring commitments (e.g. with initiatives showcasing the implementation of a Universal Design for Learning and blended learning programmes combining face-to-face teaching with online learning interactive sessions), similarly, before the pandemic, few universities provided online learning (Universities UK, 2018). More specifically, despise an increase in UK higher education institutions offering online provision from 102 in academic year 2010-11 to 117 in academic year 2016-17, during the latter period, online learning made up only $8 \%$ of all the provision in UK higher education institutions. Furthermore, a single institution, The Open University, accounted for a total of $65 \%$ of that online learning provision, leaving other institutions only at $35 \%$. (p. 14). In other parts of the world, where online learning may be expected to be high, such as in the US, according to the National Centre for Education Statistics, as of fall 2018, the proportion of students who were enrolled exclusively to a distance education courses accounted for just 16.6\% (U.S. Department of Education, 2018).

In relation to online education, the building stones for planning a sustainable cohesive, independent and robust strategy for dealing with the pandemic may have already been in place for some universities that have endorsed pre COVID-19 the vision of a changing digital education reality, which emerged much earlier than the global pandemic crisis. Although future research may elaborate this idea further, it is 
likely that universities that had already invested in online infrastructure, training for teaching and learning as well as the development of effective online pedagogies, felt much more prepared to deal with switching to online delivery only. However, considering the above statistics, COVID-19 has caused an unprecedented disruption in Higher Education with the majority of universities across the globe working immensely to plan and offer a fast and efficient response for fully implementing online learning, mostly lacking experience of the most efficient online infrastructure, the pedagogical expertise and the training that is required for staff to deliver this type of learning to their students. More importantly, from the learner's point of view, the sudden shift to this online learning reality could be described as a 'forced migration' to online learning design and pedagogy. What this means is that, whereas before, on-campus provision of learning and teaching experiences would be, in most cases, just enhanced or supplemented by off-site online provision, with the effects of COVID-19, there has been a complete and involuntary shift, reversing priorities and the positioning of online provision in universities. This new 'forced' online teaching and learning reality has opened the door to multiple challenges which are complex and ongoing. How to implement remote tools and practices en masse ensuring accessibility and equity for all? How to upskil both staff and students in the use of ICT tools for teaching, learning and communication? How to train staff on online pedagogical approaches and prepare students to embrace the principles of distance education?

Relying solely on remote tools and online technologies to roll out processes creates, by default, management challenges around how to help students swiftly and effectively transition from face-toface on-campus learning and teaching to online and blended provision, in a way that requires minimal campus attendance but ensures optimal student outcomes. Undoubtedly, this type of emergency online course redesign and delivery poses many additional questions, related to the above, such as 'are all the students able to participate synchronously in an online class and how to overcome accessibility and engagement equity barriers in online participation?' Even when practical issues, that deal with accessibility or the use of technology (e.g. what platform, which video conferencing tools to use) are tackled, it can be challenging for both students and academics with limited or no prior experience of learning/teaching online to deal with these changes. For example, 'how best to deliver live practice sessions that would normally be offered during hands-on workshop in class, where synchronous person presence and non-verbal communication is essential?' or 'how to ensure that students are encouraged to directly and actively engage with reading material and resources?', or 'how to make online classes interactive via discussion, group work and other forms of active learning?' and 'how to run virtual fieldwork placement experiences?'. Even in classes that may take place on-campus, on a blended learning mode, experienced educators may be critically thinking about what strategies they might employ to engage their students in meaningful learning, in situations where, for example, class experiences have to be altered by social distancing requirements, (e.g. by the necessity to wear a face mask which may create barriers to effective non-verbal communication, such as expressing interest or 
confusion, conveying understanding of the taught topic, hearing and understanding each other) or when there is a need to reduce crowded spaces in their physical classrooms.

However, the questions that emerge are not just about transferring or delivering educational content or resources online. Any experienced online tutor would recognise that studying online requires different learning and digital communication skills that enable online collaboration, engagement, communication, interaction, knowledge acquisition and problem-solving to take place. These requirements present the need to cultivate modern digital social skills, in addition to the advancement of the subject direction. When students start their online courses, for example, they do not have the same opportunities to socialise, as they would do under normal circumstances when they meet face-toface with other learners. Lack of clarity and direction on how to communicate, interact, learn and problem solve online can create confusion and stress to students, especially when they have not chosen to study online or they are not accustomed to this way of learning. Considering this notion in the context of COVID-19 reduced social interaction, lack of community engagement that would normally happen on-campus, may also fall short of fulfilling the emotional vacuum or supporting the wellbeing of learners.

However, COVID-19 has also changed the boundaries between formal and informal communication, challenging existing codes of practice and conduct in online working settings. It was not long ago, just back in 2017, when Professor Robert Kelly experienced an 'unexpected distraction' while he was being interviewed live on BBC News about South Korea (BBC News, 2017; Usborne, 2017). The video, which became viral, captured the imagination of people around the world, as it presented a common professional fear: informal events in everyday life mixing up with the formal professional sphere. In that case, it was a young family and a wife interrupting a live professional interview. Although Professor Kelly managed to keep his professional composure and persona intact by continuing the formal interview successfully, an incident like that created interesting public debates, as at that time as such incidents were still an unusual and uncommon occurrence. Post COVID-19, professionals, across the globe, have now opened the virtual doors to their houses and families, while 'home-working' is established as the new standard. Informal encounters with family, pets and sudden interruptions are not only a natural phenomenon but, often, an expected one. This new reality is challenging the way in which learning online can be delivered, humanising the curriculum and blurring the boundaries between everyday life and formal education. As online social etiquette codes are changing and moving into the realm of the 'informal', new opportunities may be created for easier and faster collaboration and innovation, taking down procedural barriers. 


\section{The role of academic librarians post COVID-19: challenges and opportunities}

During COVID-19, in a similar vein, academic librarians have been encountering all the above challenges and opportunities experienced in the changing online education environment, as they are called to work remotely, deliver access to resources solely electronically and teach almost exclusively to an online audience. With many academic librarians' roles involving teaching responsibilities and information skills related support, awareness of technical considerations for connectivity as well as design for online education and understanding of accessibility barriers faced by students and staff have been a priority. Even before COVID-19, there was no guarantee that students or even staff, who studied or worked on-campus, would have a stable or reliable access to the Internet or the necessary digital technologies at home that would allow them to switch to a complete remote way of working or learning. This is the case, particularly with people who experience inequalities, not just on the basis of internet connectivity (access to the Internet) but also from the perspective of digital competences development. Digital competences is a complex umbrella concept that relates to the development of an number of competence areas, including information and data literacy, communication and collaboration, media literacy, creating online content, online safety and digital wellbeing as well as problem solving, critical thinking and innovation with online tools and technologies. Digital competences encompass not only information and communication tools and technology related skills but also attitudes and behaviour that relates to the online information and communication environment, which address responsible, ethical and safe use and dissemination of information, as well as developing creative and innovative approaches when using digital media for learning, work, and everyday life societal participation to fulfil personal, social or commercial goals (Carretero et al., 2017; Laurillard et al. 2016). The UK Digital Strategy (2017) highlights that "for the UK to be a world-leading digital economy that works for everyone, it is crucial that everyone has the digital skills they need to fully participate in society..." (UK Department for Digital, Culture, Media \& Sport, 2017). However, a digital skills survey conducted in 2018 in the UK found that " 11.3 million people (21\%) lack the full basic digital skills" and " 4.3 million ( $8 \%$ ) have no basic digital skills at all", while "5.4 million working adults (10\%) are without basic digital skills" (The UK Department for Education, 2019). There is therefore a need to equip the modern workforce and society overall with digital skills that will help to address future challenges (UK Department for Digital, Culture, Media \& Sport (2017).

Whereas libraries with an existing online student population and staff, who were accustomed to remote working pre-COVID-19, may already be well positioned to offer a range of online services (such as online guides to specific databases, online tutorial provision, interactive live sessions/courses/seminars, online one-to-one support, online referencing templates and research techniques video overviews) libraries with a less stronger online presence are now called to reinvent themselves and evolve an entire suite of online services, moving to a new era of digital transformation. In both cases, academic libraries 
are called to critically evaluate priorities for training and support and for services that can be delivered remotely in light of both the temporal restriction to access to physical buildings and the future needs that may be created with a second wave of the pandemic, causing further uncertainty.

In response to the measures that were placed in universities during to the COVID-19 outbreak, there was a proliferation of publishers/ suppliers, who offered on a temporal basis, increased or free access to resources for supporting students and academics with online teaching, beyond their normal offerings (a few indicative examples include Bloomsbury Professional, EDP Sciences Journals, JSTOR public health journals, Microbiology Society, Pharmacy Knowledge, ScienceDirect eBooks, University of Michigan Press eBooks, and vLex Justis among others) (Robert Gordon University Library, 2020). For instance, as a response to the pandemic and the need for public health information, JSTOR made available 26 public health journals, for free access covering topics such as epidemiology, health policy, occupational and environmental Health and health promotion (JSTOR, 2020). Elsevier temporarily opened up access to over 250 textbooks for universities that subscribe to ScienceDirect (Elsevier, 2020). Moving beyond the pandemic academic libraries are called to advocate for the rights of open access for their students and staff. Again, even before COVID-19, academic librarians were well placed to provide guidance and institutional support to academic researchers publishing via open access. Academic libraries have been at the heart of open access as its ethos focuses on facilitating "the sharing of knowledge for the benefit of the wider public good, a mission that closely aligns with the ideals of librarians and the institutions they serve" (Royal Society of Chemistry, 2015). Libraries have a good general knowledge of open access, however, keeping up with changes to open access policy may create challenges and understanding the requirements of the various funding bodies may create confusion. These were, for example, key findings of a survey of librarians and information specialists working in chemistry and related subjects conducted by the Royal Society of Chemistry (2015). Post COVID-19 greater advocacy for the need of open access as well as training in this area can help to further strengthen the key positioning of academic libraries in the Open Access debate.

Furthermore, during the pandemic, academic libraries were involved in actively offering additional services around the curation of resources related to the COVID-19 outbreak to help academic researchers advance their understanding as well as help them increase awareness of the importance of information evaluation for the public as a protective mechanism against the COVID-19 'infodemic' (World Health Organization, 2020). During COVID-19 social media tools became primary information sources on the pandemic crisis (Neem and Bhatti 2020), spreading misconceptions, harmful claims and unreliable content, such as the claims about the role of $5 \mathrm{G}$ as a causing factor in the pandemic or that drinking alcohol could protect people against COVID-19 (Neem and Bhatti 2020). Great examples of curating resources have emerged by different academic libraries in the fight against the 'Infodemic'. For example, The University of Vermont Libraries offers research guides containing a number of freely 
available resources for clinical care, patient information resources, literature search resources, as well as publishers providing free access to COVID-19 information (University of Vermont Libraries 2020). Yale University Library has created a guide which is a working collection for researchers looking to explore the impact of COVID-19 across social science disciplines (Yale University Library, 2020). UCL Library Services offer a reading list with official guidance, current evidence updates, UK Medical Organizations and e-Learning training courses, open access research collections and medical library resource guides (UCL Library Services, 2020).

The COVID-19 pandemic stressed even more the important role of academic librarians in helping students to develop information, digital and media literacy skills so that they can be in a position to independently select, access and use accurate, reliable, trustworthy and credible sources of information, not only for their studies but also for their own wellbeing. During COVID-19 the surge of circulating false claims and information online via social media and fake news, made it equally difficult for students to decipher misinformation/disinformation from accurate and reliable information. In the UK, "Making Sense of Media Network" consisting of organisations and individuals with expertise in media literacy with a focus on improving online skills, knowledge and understanding of UK adults and children, published weekly research findings on the attitudes of the public around news consumption and misinformation related to the pandemic. For example, interestingly, the findings published during week five of the UK 'lockdown' in the early summer of 2020 , found that $50 \%$ of respondents had come across misinformation and that younger people aged 16-24 (many of which could be students) were the most likely to come across misinformation (38\%). More alarmingly, almost three in ten people responded "don't know" to this question, possibly indicating that they may have come across misleading information they could not recognize (Ofcom, 2020).

\section{Lessons learned}

What are the lessons we have learned from these challenges? It is becoming clear that COVID-19 has created a reality of remote working and learning in Higher Education institutions that may remain for longer than initially envisaged. With remote working being the norm rather than the exception, universities are called to invest not only in remote working infrastructure and digital tools but to also devise systematic and structured approaches for a new era which requires a different working ethos, and organisational culture as well as the establishment of new supporting mechanisms for both staff and students that will help them to develop new skills, boost their morale, keep social connections and create an overall sense of belonging and wellbeing.

From a managerial perspective, reviewing what existing connectivity gaps, support mechanisms and training needs may be present in academic libraries, in light of this 'new normal' caused by the 
pandemic, has been and continues to be a key element in assisting the smooth transition to remotely working and learning. In addition, in these efforts academic libraries are called to not just implement temporal changes. There is an opportunity to be changing agents by means of engaging synergistically and proactively with schools, research services, IT support, individual educators and students, learning/ teaching support professionals as well as with the wider body of academic librarians working in different academic settings. Engaging in critical discussions and creative collaboration will ensure that academic librarians do not only just better understand current needs but also predict and design for emerging trends and future needs following the most efficient and effective strategies for smoothly migrating to a new post COVID-19 era. Furthermore, with uncertainty at the center of this new reality, risk assessment and contingency planning should continue to feature high the planning agenda of academic libraries, with restrictions placed to the physical access and with changing requirements for social distancing which may render some academic libraries to operate solely online for a longer period, supporting students and staff remotely, while others may give priority to blended learning provision with hybrid presence of campus and online services.

Moving on, academic libraries require clear operation plans for online provision but also for the safety measures and logistics that will allow the smooth operation of blended learning, keeping both staff and students safe, and addressing measures for monitoring the number of library staff present on-campus, ensuring social distancing of staff and students who visit the library and replacing physical meetings with online meetings. Clear processes are also needed for the sanitation and disinfection of books and other resources, keeping on the monitoring of research on how materials should be handled to mitigate risk of exposure to the virus (Institute of Museum and Library Services 2020).

However, beyond the many and complex challenges, what are the lessons for the opportunities created? What is certain is that the pandemic, for most universities and their academic libraries has been a catalyst for change, highlighting the importance of having a robust strategy for facilitating the remote operation of the academic library as a priority. Even to those who may have been skeptical to these changes, or less welcoming, the crisis response experience, has presented more than just a lesson on how to deal with crisis situations. It has offered an unprecedented opportunity for 'disruptive innovation' for even the most resistant universities, that were forced by the circumstances, to place, at least temporarily, e-learning in the front of teaching and learning agenda, changing dramatically how classes were delivered with academic staff designing classes with an emphasis on flexible and interactive ways of learning and teaching. This rapid shift could be now endorsed by all universities and access to a proliferation of different platforms and tools for digital learning available could make this possible. 
In addition, this is a unique opportunity for academic libraries to plan, design, and roll out a sustainable future plan for establishing online education on information skills and digital literacy as a normative provision, focusing on creating more impactful ways of learning for students and building online learning communities.

Within that new reality there is a clear need to also focus on the evolving role of the academic librarian in terms of the need for training in pedagogic theory and practice, online curriculum design, and mechanisms that will ensure their ongoing personal and professional development. With COVID-19 there have been a number of opportunities for continuing professional development, as several organisations, previously only delivering in-person training, have now developed a range of Continuing Personal Development (CPD) training material, resources, online seminars, online conferences and opportunities to virtually meet online. For example, The Scottish Library and Information Council (SLIC) lists a number of organisations offering online training, including Carnegie Trust Stepping into Leadership, CILIPS - Online Learning, Culture \& Wellbeing Community Network Scotland, Libraries of Sanctuary Resource Park, British Library - Webinars, Design Thinking for Libraries Toolkit, The Open University, and University of South Carolina - Librarian Support (SLIC 2020). In addition, academic libraries around the world, offer open access to a wide range of information and digital literacy resources. Emerging online communities on information, digital and media literacy, such as OneHE Mindsets, Information Digital and Media Literacy open community of practice (CILIPS, 2019; OneHE 2020) offer a series of webinars and curated information to help information professionals, academics and learning and teaching support staff to connect and explore in dialogue the challenges in HE around the themes of information, digital \& media Literacy.

More importantly, the key positioning of academic librarians in this new agenda presents novel opportunities for being actively involved in key collaboration global initiatives which are designed to further promote the future of online learning and teaching in Higher Education. For example, with "some 1 billion students and youth across the planet... affected by school and university closures due to the COVID-19 outbreak" UNESCO recently launched the Global Education Coalition to help countries develop expertise and share knowledge around distance learning practices (UNESCO, 2020a), embracing inclusivity and endorsing the significance and value of investing in "flexible education systems for the future" (Giannini, 2020). In addition, UNESCO, in cooperation with the European Commission, Twitter, and the World Jewish Congress, launched a series of visual learning resources in the form of infographics to raise awareness of phenomena on the rise during COVID-19, including the existence and consequences of conspiracy theories (UNESCO, 2020b). The European Commissions' 'Fighting Misinformation' is a dedicated online space for tackling Misinformation and disinformation issues in response to the Global Pandemic, highlighting the need to rely on authoritative sources and 
declaring the fight against disinformation as "a joint effort involving all European institutions" (European Commission, 2020).

The Global MIL Week 2020 (24-31 October) will address the theme of 'Resisting Disinfodemic: Media and Information Literacy for everyone, by everyone' (UNESCO, 2020c). Academic libraries should demonstrate active presence in such events and embark on open collaboration in a way that promotes their expertise and advocates for their values.

\section{Conclusions}

The new reality faced by academic libraries presents innumerable financial, administrative and pedagogical challenges created by the current declining economic climate and the significant pressure placed by the pandemic to reduce students' presence to the physical campus. The migration to a seamless provision of online resources and services to meet students' needs, in their transition to online learning environments, has not only put extra pressure on libraries but also placed a lot of uncertainty about the future. The current severe economic devastation prevailing in society and the economy overall, as well as the years of predicted austerity that is yet to come may be challenging the sustainability of universities, particularly those based on students' tuition and thus the sustainability of their academic libraries as well. A prolonged interruption to campus services may create a situation where the provision of traditional library services, mostly based on physical material and face-to-face interactions may be challenged, or deemed to be less necessary by students or staff. This may be further reinforced by the prevailing misconceptions existing in society (and often in educational environments) that information needed could be just a click away, sourced freely online.

However, in the middle of this crisis, it is also becoming clear that COVID-19, beyond the clear challenges and increasing uncertainly, may be providing the building blocks for planning a future sustainable cohesive, independent and robust strategy for dealing with what has been a changing education reality. As academic libraries move forward, they have a renewed mission to help learners in the online space to become information rich and digitally competent, as well as empower them to overcome digital divides and inequalities. The advancement of digital competences is fundamental for students' education and for the battle against fake news, misinformation and disinformation but this area is currently lacking a clear agenda in Higher Education with contested interests. Academic libraries are well placed to act as the connecting link that will help to move a strategic vision that places design for equity at the center of education, a step forward, supporting students from different backgrounds to overcome socio-cultural barriers in their access to online information and their digital competences development as they transition in and out of Higher Education. Academic libraries are also well positioned to increase awareness in academic staff of current information and digital literacy related 
issues faced by students and, in the post COVID-19 new information realities, become changing agents in the ways in which students learn, engage, interact and create with online information.

In universities that have previously invested in the delivery of online teaching and learning and the provision of e-resources and services for students and staff, the new reality also presents renewed opportunities to think critically about unified efforts and creating powerful consortia that could support these efforts. Unless academic librarians are open to collaboration and embrace a renewed agenda, there is the danger that post COVID-19 they could be rendered invisible. There are many collaboration examples, that could be used as proof that joint library efforts could work when there is a unified vision. For example, The Scottish Higher Education Digital Library (SheDL) is an excellent example of a consortium that permits the joint licensing of publisher providing members of Scottish universities and institutes with access to over 3000 journals and 60,000 eBooks) (Stevenson, Ashworth, and Evans, 2018; SCURL 2020). The International Coalition of Library, which "supports participating consortia by facilitating discussion on issues of common interest comprising approximately of 200 library consortia in North and South America, Europe, Australia, Asia, and Africa", lists a number of thematic consortia working together across the world (Consortia (ICOLC, 2020).

Finally, library schools should also continue to update their curricula to focus on the future challenges and prepare a new generation of librarians to take on leadership roles within the important digital literacy domain as well as the Open Educational Resources (OER) movement. Perhaps, if there is something positive about COVID-19 and what it has taught us about academic libraries is that they could sustain a service that has built its foundations on physical resources only and that online learning may be around for longer than expected.

\section{References}

BBC News YouTube (2017), "Children interrupt BBC News interview - BBC News", ”, available at: https://www.youtube.com/watch?v=Mh4f9AYRCZY (accessed 14 September 2020).

Carretero, S., Vuorikari, R. and Punie, Y. (2017), DigComp 2.1: The digital competence framework for citizens with eight proficiency levels and examples of use, Publications Office of the European Union, Luxembourg.

CILIPS (2019), “Mindsets: Open Community for Information, Digital \& Media Literacy”, available at: https://www.cilips.org.uk/mindsets-information-digital-medialiteracy/ (accessed 15 September 2020). 
Crown Commercial Service (2016), "Digital Training and Support", available at: https://www.contractsfinder.service.gov.uk/Notice/c887d39a-626d-43a4-982ae39bf5de6048?p=@jJNT08=UFQxU1RRPT0=N (accessed 15 September 2020).

EBLIDA. (2020) “A European Library Agenda for the post-Covid 19 age [work in progress] Draft May, 2020", available at: http://www.eblida.org/Documents/EBLIDA-Preparing-a-Europeanlibrary-agenda-for-the-post-Covid-19-age.pdf (accessed 14 September 2020).

Elsevier (2020), "COVID-19 resources for librarians, campuses and health professionals" available at: https://www.elsevier.com/connect/coronavirus-initiatives (accessed 15 September 2020).

European Commission (2020), "Fighting disinformation", available at: https://ec.europa.eu/info/livework-travel-eu/health/coronavirus-response/fighting-disinformation_en\#identifyingconspiracy-theories (accessed 15 September 2020).

ICOLC International Coalition of Library Consortia (2020), available at: https://icolc.net/consortia (accessed 15 September 2020).

Institute of Museum and Library Services (2020), "Research Shows Virus Undetectable on Five Highly Circulated Library Materials After Three Days", June 22, 2020, available at: https://www.imls.gov/news/research-shows-virus-undetectable-five-highly-circulated-librarymaterials-after-three-days (accessed 15 September 2020).

JSTOR, (2020), "Now available: Free access to new Public Health journals on JSTOR" available at: https://about.jstor.org/l/public-health/ (accessed 15 September 2020).

Laurillard, D., Derrick, J. and Doel, M. (2016), "Building digital skills in the FE sector: Future of skills and lifelong learning", Government Office for Science, London, UK.

Naeem, S.B. and Bhatti, R. (2020), “The Covid-19 'infodemic': a new front for information professionals", Health Information and Libraries Journal, available at: https://onlinelibrary.wiley.com/doi/10.1111/hir.12311 (accessed 15 September 2020).

Ofcom (2020), "Covid-19 news and information: consumption and attitudes Results from week one of Ofcom's online survey", available at: https://www.ofcom.org.uk/ data/assets/pdf file/0029/197732/covid-19-news-consumptionweek-fourteen-misinformation-summary.pdf (accessed 15 September 2020).

OneHE (2020), "Information, Digital \& Media Literacy" (Mindsets), available at: https://mailchi.mp/bf15273eba8b/mindsets (accessed 15 September 2020).

Robert Gordon University Library (2020), "Resources related to the COVID-19 outbreak", available at: https://ibrary.rgu.ac.uk/covid19-resources (accessed 15 September 2020).

Royal Society of Chemistry (2015), "The role of libraries in open access publishing”. Available from: https://www.rsc.org/globalassets/14-campaigns/m/lc/1c16013/lc16013-open-access-surveyreport-librarians.pdf (accessed 15 September 2020).

SCURL (2020), available at: Scottish Confederation of University \& Research Librarieshttps://www.scurl.ac.uk// (accessed 15 September 2020). 
SLIC Scottish Library Information Council (2020), "CPD for library staff”, available at: https://scottishlibraries.org/staff-development/cpd-for-library-staff/ accessed 15 September 2020).

Stevenson, A., Ashworth, S. \& Evans, J. (2018), "The Scottish Higher Education Digital Library (SHEDL): Successes, Challenges, and the Future", in Atkinson, J. (Ed), Collaboration and the Academic Library. Internal and External, Local and Regional, National and International, Chandos Publishing, United Kingdom, pp. 195-204

UCL Library Services (2020), “COVID-19”, available at: https://rl.talis.com/3/ucl/lists/548508181708-33F7-8FFF-11E8BD0518B4.html (accessed 15 September 2020).

UK Department for Education (2019), "Essential digital skills framework", GOV.UK, available at: https://www.gov.uk/government/publications/essential-digital-skills-framework (accessed 15 September 2020).

UK Department for Digital, Culture, Media \& Sport (2017), “UK Digital Strategy 2017”, available at: https://www.gov.uk/government/publications/uk-digital-strategy/uk-digital-strategy (accessed 15 September 2020).

UNESCO (2020a), "Youth, strategic partners during the COVID-19 crisis", 30/06/20, available at: https://en.unesco.org/news/youth-strategic-partners-during-covid-19-crisis (accessed 15 September 2020).

UNESCO (2020b), "New resources to counter COVID-19 conspiracy theories through critical thinking and empathy", 14/08/20, available at: https://en.unesco.org/news/new-resourcescounter-covid-19-conspiracy-theories-through-critical-thinking-and-empathy (accessed 15 September 2020).

UNESCO (2020c), “Global Media and Information Literacy Week” available at: https://en.unesco.org/commemorations/globalmilweek (accessed 15 September 2020).

Giannini, S. (2020), “Come together, now”, UNESCO, 20/03/20 available at https://en.unesco.org/voices/covid19 unprecedent_education_emergency (accessed 15 September 2020).

UK Department for Digital, Culture, Media \& Sport (2017), "Digital skills and inclusion - giving everyone access to the digital skills they need", 11 March 2017, available at: https://www.gov.uk/government/publications/uk-digital-strategy/2-digital-skills-andinclusion-giving-everyone-access-to-the-digital-skills-they-need (accessed 15 September 2020).

Universities UK. (2018) "Flexible learning. The current state of play in UK Higher Education", available at: https://www.universitiesuk.ac.uk/policy-andanalysis/reports/Documents/2018/flexible-learning-the-current-state-of-play-in-highereducation.pdf (accessed 15 September 2020). 
University of Vermont Libraries (2020), "Research Guides. Free Medical Resources to Support Clinical Care" available at: https://researchguides.uvm.edu/freeresources (accessed 15 September 2020).

Usborne, S. (2017), “The expert whose children gatecrashed his TV interview: 'I thought I'd blown it in front of the whole world", The Guardian, 20 December 2017, available at: https://www.theguardian.com/media/2017/dec/20/robert-kelly-south-korea-bbc-kidsgatecrash-viral-storm (accessed 15 September 2020)

U.S. Department of Education National Center for Education Statistics (2018), "Fast facts. Distance learning", Digest of Education Statistics 2019, Table 311.15, available at: https://nces.ed.gov/fastfacts/display.asp?id=80 (accessed 15 September 2020).

World Health Organization (2020), "Munich Security Conference”. Speech by Director General, Tedros Adhanom Ghebreyesus, 15/02/2020, available at: https://www.who.int/dg/speeches/detail/munich-security-conference (accessed 15 September 2020).

Yale University Library (2020), "COVID-19 Social Science Research: Home” available at: https://guides.library.yale.edu/covid19impacts (accessed 15 September 2020).

Zaidi, A. Beadle, S. and Arthur, H. ICF Consulting Services Ltd. (2018), "Review of the online learning and artificial intelligence education market. A report for the Department of Education". Department of Education. July 2018, available at: https://assets.publishing.service.gov.uk/government/uploads/system/uploads/attachment_data/ file/807625/DFR_Online_learning_and_AIEd_market_review.pdf (accessed 14 September 2020). 